\title{
DURATION OF ANAESTHESIA WITH THIOPENTAL WHEN COMBINED WITH EACH OF MANNITOL, UREA, SODIUM BICARBONATE, OR TROMETHAMINE ("THAM," “TRIS")"
}

Allen B Dobin, M D, Jacob $S$ Ispael, M d, and Peter H Byles, m B

DURING THE PAST FOUR YEARS, some relatively simple cornpounds have been under trall for the treatment of serious metabolic disturbances which have long troubled the climician Mannitol and urea have been used primarly as osmotic diuretics, sodium bicarbonate has been used to reverse metabolic acidosis, and tromethamine has been used to treat both respiratory and metabolic acidosis, but it is an osmotic diuretic as well

This report deals with a study to determine whether these compounds affect the duration of thiopental anaesthesia The experuments were done because the compounds are being used more and more durng or ummednately following the administration of anaesthesia, and the authors felt that it was important to know particularly whether they alter the duration of anaesthesia

\section{Method}

Crossover experments wele carried out four times, at weekly intervals, with each drug, using 10 mongrel dogs of comparable size (initial weight 135 to 198 $\mathrm{kg}$, mean $176 \mathrm{~kg}$ ), using a technique previously employed in such studies ${ }^{123}$ Prior to each experiment, the dogs were weighed in the fastng state $(12 \mathrm{hr})$ All but one dog increased in weight during the four months (Nov 1962 to Feb 1963) that these experiments weie in progress In every experiment, each dog received $25 \mathrm{mg} / \mathrm{kg}$ of thiopental intravenously in a 25 per cent solution, injected at the approximate rate of $200 \mathrm{mg} /$ minute, and this was followed in alternale experiments by the injection of the test drug The dose selected for each of the four drugs was within the therapeutic range of its primary use In fixing the dose, consideration was given also to the matter that these data might be apphed to evaluating the combination with thropental in man

Sodium bicarbonate was injected rapidly, in a 75 per cent solution $(75 \mathrm{mg} / \mathrm{kg}$ body weight), the total dose being administered in less than 30 seconds in each case Tromethamine was injected in a 3 per cent solution $(300 \mathrm{mg} / \mathrm{kg}$ ) in 5 per cent dextrose/watei by drip infusion regulated so that the total dose was administered in 15 minutes The latter method was used also with the mannitol ( 20 per cent solution in water, $1000 \mathrm{mg} / \mathrm{kg}$ body weight) and the urea (30 per cent solution, $1000 \mathrm{mg} / \mathrm{kg}$ body weight)

After each injection, the dog was placed on the floor of the laboratory and allowed to recover without being disturbed or stimulated The recovery time of each animal was recorded as the time which had elapsed from the beginning of

From the Department of Anesthesiology, State University of New York, Upstate Medxcal Center, Syracuse, New York 
the injections until the dog lifted its head and, then, until it attempted and was able to stand on all four paws without collapsing As soon as the dog recovered, it was removed from the room so that it would not stumulate its "sleeping" companions

\section{RESULTS}

The data from the four crossover expermments are summarized in Tables $\mathbb{I}$ and II, together with a statistical analysis of each No untoward effects were observed during the injection of thiopental or during recovery in the control experiments Of the four drugs tested, two caused apparent side-effects with tromethamine, one dog retched during the injection, three dogs vomited fluid after the injection, and one dog stopped breathing abruptly some minutes after the injection and expired Three dogs vomited while the urea was being administered Durnng the recovery period, most of the anmals that received mannitol and urea urinated

Sodium bicarbonate was the only agent of the four which caused an appreciable reduction in the recovery tame from thiopental sleep Mannitol was the only

TABLE I

\begin{tabular}{|c|c|c|}
\hline Drugs & $\begin{array}{l}\text { Concentration } \\
\text { used (\%) }\end{array}$ & Chemical sin ructure \\
\hline $\begin{array}{l}\text { Mannitol } \\
\text { Osmotril@, Travenol@ }\end{array}$ & 20 & 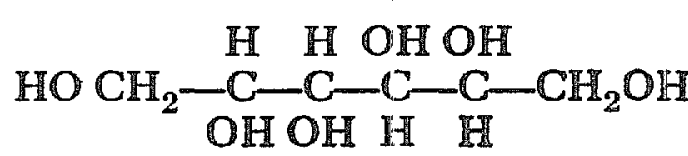 \\
\hline $\begin{array}{l}\text { Urea } \\
\text { Urevert@, Ureaphil@ }\end{array}$ & 30 & $\mathrm{H}_{2} \mathrm{~N}-\mathrm{CO}-\mathrm{NH}_{2}$ \\
\hline Soduum bicarbonate & 75 & $\mathrm{NaHCO}_{3}$ \\
\hline $\begin{array}{l}\text { Tromethamine } \\
\text { Talatrol@, “THAM," “Trns" }\end{array}$ & 30 & $\mathrm{NH}_{2}-\frac{\mathrm{C}-\mathrm{CH}_{2} \mathrm{OH}}{\mathrm{CH}_{2} \mathrm{OH}}$ \\
\hline
\end{tabular}

TABLE II

The Effect of Some Druretics on Thiopentail Narcosis in Dogs

\begin{tabular}{|c|c|c|c|c|c|c|c|c|c|}
\hline \multirow[b]{3}{*}{ Drugs } & \multirow{3}{*}{$\begin{array}{c}\text { Dose } \\
(\mathrm{mg} / \mathrm{kg})\end{array}$} & \multicolumn{8}{|c|}{ Recovery tume (mmutes) } \\
\hline & & \multicolumn{2}{|c|}{ Head up } & \multirow[b]{2}{*}{$\% \mathrm{Dif}$} & \multirow{2}{*}{$\begin{array}{c}\text { Signif } \\
\mathbb{P}\end{array}$} & \multicolumn{2}{|c|}{ Legs up } & \multirow[b]{2}{*}{$\% D_{1} f f$} & \multirow{2}{*}{$\underset{\mathbb{P}}{\text { Signif }}$} \\
\hline & & $\mathrm{Mean}^{3 / 2}$ & $\overline{S D}$ & & & $\overline{\text { Mean }}$ & $\overline{\mathrm{SD}}$ & & \\
\hline $\begin{array}{l}\text { Thiopental alone } \\
\text { +mannitol }\end{array}$ & $\begin{array}{r}25 \\
1000\end{array}$ & $\begin{array}{l}43 \\
52\end{array}$ & $\begin{array}{l} \pm 10 \\
\pm 17\end{array}$ & +23 & $<001$ & $\begin{array}{l}54 \\
68\end{array}$ & $\begin{array}{l} \pm 11 \\
\pm 18\end{array}$ & +26 & $<0001$ \\
\hline $\begin{array}{l}\text { Thopental alone } \\
\text { turea }\end{array}$ & $\begin{array}{r}25 \\
1000\end{array}$ & $\begin{array}{l}48 \\
54\end{array}$ & $\begin{array}{l} \pm 22 \\
\pm 18\end{array}$ & +13 & $<002$ & $\begin{array}{l}60 \\
65\end{array}$ & $\begin{array}{l} \pm 20 \\
\pm 18\end{array}$ & +12 & $>005$ \\
\hline $\begin{array}{l}\text { Thropental alone } \\
+\mathrm{NaHCO}_{3}\end{array}$ & $\begin{array}{l}25 \\
75\end{array}$ & $\begin{array}{l}66 \\
42\end{array}$ & $\begin{array}{l} \pm 15 \\
\pm 11\end{array}$ & -27 & $<005$ & $\begin{array}{l}84 \\
66\end{array}$ & $\begin{array}{l} \pm 36 \\
\pm 17\end{array}$ & -24 & $<0001$ \\
\hline $\begin{array}{l}\text { Thropental alone } \\
\text { +THAM }\end{array}$ & $\begin{array}{r}25 \\
300\end{array}$ & $\begin{array}{l}53 \\
48\end{array}$ & $\begin{array}{l} \pm 11 \\
\pm 14\end{array}$ & -11 & $<005$ & $\begin{array}{l}64 \\
62\end{array}$ & $\begin{array}{l} \pm 31 \\
\pm 15\end{array}$ & -2 & $>005$ \\
\hline
\end{tabular}

Each mean thme repiesents 20 administrations of thiopental alone and 20 with the test drug, except in the "THAM" expenzaents un which each mean tume represents 18 adminustrations 
one which caused an appreciable lengthening of the duration of recovery Urea appeared to produce a trend to lengthening while tromethamine appeared to produce a shortening of the duration of recovery, but these effects were not very significant statustically

\section{DisCUSSION}

Mannitol, a hexahydroxy alcohol (the reduced forin of Mannose), is prepared erther as a sterle 25 per cent aqueous solution or as at sterle 20 per cent aqueous solution which is buffered at a $\mathrm{pH}$ of 64 to 68 with "odium hydroxide Although mannitol has been used to measure glomerular filtration rate for many years, ${ }^{*}$ it has now been found to be of value as a therapeutic agent to reduce elevated cerebral spinal flud pressure ${ }^{5}$ and intraocular pressure ${ }^{6} \mathbb{A}$ fter intravenous infusion, it is restricted to the extraeellular flund compartment and is freely filtered by the kadney glomeruli, creating a high osmotic pressure in the lumen of the renal tubular system, causing inhibition of resorption of water and arding the irrigation of the tubules and the excretion of urne Mannitol has been shown to increase renal blood flow, decrease renal vascular resistance, and ieduce the haematocrit, associated with marked alteration in the shape and diminution in the size of ired blood cells ${ }^{7}$ It promotes the excretion of sodium and chlonde, along with water, without appreciably increasing potassium excretion Mannitol also appears to be an effective prophylactic agent against functional renal fallure in surgical procedures in which serious renal effects are prevalent, particularly those incidental to vascular (aneurysmectomy) and cardlac surgery ${ }^{8-13}$ It is also used to promote druresis in exogenous and endogenous intoxications as seen with overdoses of sedatives, unc acid nephropathy, and transfusion reactions ${ }^{14-18}$ The recommended unital test dose in man is $200 \mathrm{mg} / \mathrm{kg}$ administered in 3 to 5 minutes If there is an adequate response by passage of at least $40 \mathrm{ml}$ urne per hour, then larger doses may be given In our clinical use of mannitol, no obvious side-effect has been observed durung the penod of anaesthesia for vascular surgery, aside perhaps from an expected increase in unnary output, nor dud it appear to prolong the duration of anaesthesia, as occurred in the experiments reported above

Considering its action in the body, one might expect that mannitol would reduce the effect of a single large dose of thiopental by increasing the rate of excretion in the urine On the other hand, this action may, in the acute experiment, cause a persistently higher blood level by its osmotic effect and so explam why thiopental sleep may instead be prolonged Nahas and associates have suggested that the depressant action of mannitol might be due, in part, to the osmotheally unduced shift of water from intracellular to extracellular compartments and a resulting increase in the alkalinity of the chemosensitive cells However, they state further that the alterations in acid-base balance between intracellular and extracellular compartments produced by mannitol result in respiratory changes which cannot be accounted for by the classical theories relating pulmonary ventilation to hydrogen ion or $p \mathrm{CO}_{2}$ changes in arterial blood ${ }^{19}$

Urea is a powerful osmotic diuretic which has been used chnically for more than 100 years In a 30 per cent solution with 10 per cent invert sugar in water, it is now used primarily to lower intnacranial pressure, as recently recommended by Javd and Settlage, ${ }^{20}$ although it is also recommended for the treatment of 
oliguria following burns, surgery, and trauma, ${ }^{21}$ but its use in these conditions is still being evaluated Rosomoff ${ }^{22}$ has shown that urea causes water to shift from brain tissue to the cei ebrospinal fluid and the blood, doubling the volume of the latter fluid compartments and reducing the brain water to the same extent as can be accomplished by inducing hypothermia

The urea preparation is usually given in a dose of 1 to $15 \mathrm{gm} /$ per $\mathrm{kg}$ body weight, by intravenous infusion in one to two hours Maximum effect on the brain is said to occur in one to two hours and persists for 3 to 10 hours This solution is contraindicated in patients with poor renal function and serious tissue damage occurs if it is allowed to leak from the vein

The explanation for the trend to longer duration of anaesthetic "sleep" rather than its abbreviation is probably the same as with mannitol A reason why more prolonged sleep was not evident is perhaps that urea, when administered relatively quickly, appears to cause medullary irritation as manifested by the incidence of retching and vomiting Limitations inherent in the experimental design made it unfeasible to administer the urea preparation more slowly without using a longer-actung intravenous anaesthetic

Sodium bicarbonate administered intravenously causes the excretion of an increased volume of an alkaline urine The initiating event is an increase in the concentration of bicarbonate in the extracellular fluid and glomerular filtrate, consequently, there is a rise in the bicarbonate load delivered to the renal tubule Bicarbonate reabsorption results indirectly from hydrogen ion-sodium ion exchange between the tubular cell and tubular urme With high bicarbonate loads, the amount of hydrogen ion which reaches the tubular urine is not sufficient to convert all of the filtered bicarbonate to carbonic acid and $\mathrm{CO}_{2}$ Thus, bicarbonate ion with equivalent amounts of cation and an isosmotic quantity of water will escape absorption and augment the urine volume Sodium bicarbonate is not used as a diuretic clinically because it does not mobilize oedema fluid and it may cause chronic alkalosis which reduces the effectiveness of mercurial diuretics 2324

The use of sodium bicarbonate has recently come into prominence for the treatment of metabolic acidosis which follows induced hypothermia or prolonged severe cardiorespiratory depression, as well as that following circulatory arrest, poisoning with methyl alcohol, phenol, polymeric phosphates, formalin, and salncylate intoxication in children ${ }^{25}$

Huckabee has shown that metabolic acıdosis develops rapidly durnng severe hypoxia on account of anaerobic glycolysis ${ }^{26}$ and Clowes and his associates have shown that postoperative patients do poorly when they have metabolic acidosis as well as hypoxia ${ }^{27}$ Ebert and his associates have shown that ventricular efficiency is greater during metabolic alkalosis than durnng metabolic acidosis, ${ }^{28}$ and Thrower and his associates have attempted to show that the cardiovascular response to vasopressors is augmented or restored when metabolic acidosis is reduced by sodium bicarbonate ${ }^{29}$ Ledingham and Norman have demonstrated that following circulatory arrest netther a high arterial $p \mathrm{CO}_{2}$ nor variation of the arterial $\mathrm{pH}$ seems responsible for inadequate myocardial function, but when the metabolic acidosis is present and is treated by administration of sodium bicarbonate, the response to vasopressors is augmented and recovery is more likely ${ }^{30}$ 
More reliable data are still required on this subject, but cricumstantial evidence points to some benefit with alkalizing drugs as a part of acute resuscitative treatment In man, the recommended initial dose of sodium bicarbonate $1560 \mathrm{mg} / \mathrm{kg}$ body weight, using a 375 per cent solution This dose is said to raise the carbon dioxide content of the blood approximately $1 \mathrm{mEq} / \mathrm{L}$ ( or 2 vol $\% \mathrm{CO}_{2}$ ) However, alkalınization should be attempted slowly, as the patient's condition permits, and the effect of each mjection should be followed by determination of the arterial blood $\mathrm{pH}$ and $p \mathrm{CO}_{2}$ In the starved, dehydrated patient, it must be realized that treatment of metabolic acidosis in this way may aggravate a potassium deficiency and cause sodium intoxication

The dog appears to require a somewhat higher dose of sodium bicarbonate than that recommended in man to accomplish a similar reduction in fixed acids. ${ }^{30}$ Therefore, in this study, a 75 per cent solution was used and a total dose of 75 $\mathrm{mg} / \mathrm{kg}$ body weight was administered Although there 1s no reason to believe that the animals became hypoxic because of respiratory depression, and developed a metabolic acidosis, perhaps the finding that thiopental "sleep" was shortened by the administration of sodium bicarbonate points to yet another mechanism by which this substance is useful in the treatment of severe cardiorespiratory depression

Tromethamine was first used in vivo by Nahas, in 1959, to show that this organic buffer might be useful in the treatment of acidosis due to either renal (metabolic) or respiratory imparment, and would be eminently useful because it distributes widely through body fluds, does not contain sodium, and acts also as an osmotic diuretic. ${ }^{31}$ This work was confirmed by Miller, Brindle, and Gilbert ${ }^{32}$ The fact that tromethamine is a non-sodium-containing buffer is of particular importance for the patient with cardiac disease, since the only other agents used to combat acidosis are sodium bicarbonate and sodium lactate-which in a 45 $\mathrm{mEq}$ dose contain $25 \mathrm{gm}$ of sodrúm

When administered intravenously, this compound acts as a weak base which reacts, as follows, with acid metabolites

$$
\left(\mathrm{CH}_{2} \mathrm{OH}\right)_{3}-\mathrm{NH}_{2}+\mathrm{HA} \leftrightarrows\left(\mathrm{CH}_{2} \mathrm{OH}\right)_{3}-\mathrm{C}-\mathrm{NH}_{3}++\mathrm{A}^{-}
$$

In the body, $A^{-}$may be bicarbonate, chlonde, or lactate The more acid that 15 present, the more the reaction moves to the right The acid-neutralızing effect of tromethamine is thus quite similar to that of sodium bicarbonate At $\mathrm{pH} 740$, it is 70 per cent ionized and at $\mathrm{pH} 60$, it is virtually completely ionized Tromethamine is very soluble in water and is isosmolar with blood in a 03 molar solution To reverse respuratory acidosis, it buffers carbonic acid, thus lowenng the arterial $p \mathrm{CO}_{2}$ In the kudney, it acts as an osmotic duretic, there is a fall in haematocrit, indicating that a redistribution of body water takes place from intracellular to extracellular space, increasing the excretion of sodium, potassium, bicarbonate, and chloride, and increasing the $\mathrm{pH}$ of the urne Cardiac eflects of tromethamme have been described as indirectly due to reversal of metabolic and respiratory acidosis, thereby increasing the contractile force and inotropic response to sympathommetic ammes ${ }^{33}$ One report states that tromethamme (as well as urea) significantly shortens the sleeping time in rats after pentobarbital administration, but no actual data were published ${ }^{34}$ 
Nahas and associates ${ }^{19}$ have postulated that tromethamine alters the ratio of tree to combined carbon dioxide and acts on the respiratory centre either indirectly by a lowering of the $p \mathrm{CO}_{2}$ in extracellular fluid or directly by intracellular buffering They attribute an early depression of ventilation to the lowering of $p \mathrm{CO}_{2}$ in the extracellular fluid and a subsequent depression (which occurs in the presence of an elevation of $p \mathrm{CO}_{2}$ in extracellular fluid) by the penetration of tromethamine into the cells of the respiratory centres where it will accept hydrogen ions and increase buffernng capacity However, theie is stll no clear explanation for the neurophysiological mechanism which brings about the decrease in pulmonary ventilation with tromethamine or mannitol

In clinical use, this compound can restore buffer base to normal levels and may be useful in restoring the response to resuscitative measures In adults, the buffer may be used in 03 molar solution and $500 \mathrm{mg} / \mathrm{kg}$ given in one hour, or 36 grams may be given in $500 \mathrm{ml} 5$ per cent dextrose in water (06 molar) In children, it is best to dilute 9 grams in 150 $\mathrm{ml} 5$ per cent dextrose in water and to give $50 \mathrm{ml}$ in the first hour for treatment of salicylate poisoning However, indiscriminate use of this buffer is inadvisable and it should not be used unless conventional methods of therapy are ineffective ${ }^{35} 36$

Unfortunately, its administiation intravenously carries with it two senous dangers by reducing the responsiveness of the respuratory centre to carbon dioxide, it causes respiratory depression and even apnoea, therefore, it is essential to provide automatic intermittent positive pressure breathing during its administration Since this is true, it is probably unwise to use it for the treatment of respiratory acidosis, since intermittent positive pressure breathing accomplishes the same thing The other drawback is one that is similar to mannitol and ureathey cause tissue damage when they leak around a vein $A$ further drawback to use of tromethamine is that large doses cause severe hypoglycaemia, so that it is necessary to administer dextrose in water along with it ${ }^{37} 38$

Although Nahas has stated that tromethamine stumulates respiration in the dog anaesthetized with thiopental sodium until $125 \mathrm{gm} / \mathrm{kg}$ is exceeded whereas respiratory depression occurs when $150 \mathrm{gm} / \mathrm{kg}$ is administered, it was obvious to us that as little as $300 \mathrm{mg} / \mathrm{kg}$ can cause persistent apnoea (and death) in the dog In any case, our experument did not show any significant effect which would lead to a more rapid i ecovery from thiopental "sleep," although there was a slight trend in this direction

Many examples can be cited in which an unpredictable and, often, a serious effect has been produced after administering two or more drugs in combination This is particularly true in anaesthetic practice where we are dealing with potent hypnotic, analgesic, and relaxant drugs that are potentially intense cardiorespiratory depressants themselves Yet, very little work has been done specifically to study the effect of drugs in combination Loew $\mathrm{e}^{39}$ has informed us of the imprecise concepts of synergism and antagonism, and we have been reminded that much more expermental work needs to be done on drug interactions, both in animals and in man $\mathbb{A}$ leading article recently pointed out that such work requires many experimental subjects and is very laborious and tume-consuming, particularly in man, but it can yreld essential information which cannot be gained in other ways and is much less well-known than it should be ${ }^{40}$ 
Blood buffers and osmotic diuretics are now beirg used in treating patients who are sernously ill, and who, more often than not, are recerving anaesthetic agents, cardiotonic drugs, and other therapeutic agents which may facilitate recovery, but they may be instrumental in hastening death-as Calesnick and his associates found when other combinations of therapeutic agents were used ${ }^{41}$

Therefore, it behooves the anaesthesiologist to leain not only the brochemical and physiological effects of each new therapeutic drug that he may be asked by a surgeon to administer during an anaesthetic, but he should ascertain also how the drug may change the response to general (or spinal) anaesthesia-otherwise, he will on occasion be left alone with a patient at the end of an operation, wondering why certain vital signs are so depressed or have falled to return in the expected tume Furthermore, the surgeon who studies new therapeutic agents should more often realize and consider the additionil effects of the anaesthetics used on his patients, for these alone can greatly aller the over-all efficacy of a new treatment ${ }^{42}$

\section{Summary AND Conclusions}

Crossover experiments were carned out on ten mednum-sized mongrel dogs using intravenous injections of a therapeutic dose of mannitol, urea, sodium bicarbonate, and tromethamine (THAM), to determine whether any of these would alter significantly the duration of thiopental "sleep" induced with a single intravenous dose of $25 \mathrm{mg} / \mathrm{kg}$ body weight

Mannitol, in a dose of $1 \mathrm{gm} / \mathrm{kg}$ given over 15 minutes, prolonged recovery time by approximately 25 per cent, whereas sodium bicarbonate, in a dose of 75 $\mathrm{mg} / \mathrm{kg}$ given within 30 seconds shortened recovery by about 25 per cent Urea ( $1 \mathrm{gm} / \mathrm{kg}$ in 15 minutes) and tromethamine ( $300 \mathrm{mg} / \mathrm{kg}$ in 15 minutes) had no appreciable effect on recovery time although, with urea, there was a trend to delayed recovery, whereas with tromethamine, the trend was towards more rapid recovery Urea and tromethamine caused retching and/or vomiting during administration in some of the anmals, and tromethamine caused apnoea and death in one

The biochemical effect of these drugs and the obscure mechanism of action on pulmonary ventilation were reviewed brefly along with their clinical applications The prior unpredictability of their interaction with thiopental was evident from the results, and points to the importance of carrying out such studies before employing drug combinations clinically, particularly during the course of anaesthesia Senous complications arising from the combination of therapeutic agents with anaesthetic drugs can only be prevented or managed effectively when one us aware of the specific responses that drug combinations can cause

\section{RéSUMR}

Chez 10 chiens bâtards de poids moyen, nous avons fart des expériences crorsées en pratiquant des injections endoveineuses de doses thérapeutiques de mannitol, d'urée, de bicarbonate de soude et de trométhamine (THAM) pour préciser si l'une de ces substances pouvart modıfier de façon marquée la durée 
du sommeil produut par une seule dose de thiopental I $\mathrm{V}$ de $25 \mathrm{mg} / \mathrm{kg}$ de poids

Le Mannitol, à la dose de $1 \mathrm{gm} / \mathrm{kg}$ administiée au cours de 15 minutes, a prolongé d'environ 25 pour cent la durée du révell, alors que le bicarbonate de soude, à la dose de $75 \mathrm{mg} / \mathrm{kg}$ donnée en 30 secondes, a abrégé cette durée de 25 pour cent L'urée (1 $\mathrm{g} / \mathrm{kg}$ en 15 minutes) et la trométhamine $(300 \mathrm{mg} / \mathrm{kg}$ en 15 minutes) n'ont pas influencé de façon appréciable le moment du réveil bien que, avec l'urée, nous avons observé une tendance à un révell tardif et, avec la trométhamine, la tendance était plutôt à un réveil hâtif L'urée et la trométhamine ont provoqué chez certains anımaux des nausées et/ou des vomissements au cours de leur administration et, chez un anımal, la trométhamine a entraîné l'ạpnée et la mort

Nous avons brièvement parlé de l'effet bıchımıque et du mécanısme d'actıon plutôt obscur de ces substances sur la ventilation pulmonarre ainsi que de leurs applications cliniques D'après les résultats, 1 est évident que nous ne pouvions pas prévoir leur interaction avec le thiopental, et cela souligne l'importance de faure de semblables études avant d'employer de telles associations de substances en clinique, surtout au cours de l'anesthésie $S_{1}$ l'on est bien averti des résultats spécifiques qui découlent des mélanges de médicaments, on peut alors éviter de sérieuses complıcations quı peuvent se produme après l'usage combıné d'agents thérapeutiques et d'agents anesthésiques et n'utilser ces mêmes agents qu'a bon escient

\section{ACKNOWLEDGMENT}

The authors are indebted to Mr Ronald Welgan for his devoted assistance in the laboratory Drugs for testıng were kindly supplied by Abbott Laboratones and Baxter Laboratones, Inc

\section{REFERENCES}

1 Virtue, $R$ W \& Kaster, $R$ B Effect of Megimide and Thiopental in Dogs Anesthesiology 18686 (1957)

2 Dobkin, A B \& Hardand, J H Drugs which Stımulate Affective Behaviour 1 Action of LSD-25 against Thiopentone Anaesthesia in Dogs Anaesthesia 1548 (1960)

3 Dobkan, A B Potentiation of Thiopental Anesthesia by Denvatives and Analogues of Phenothiazine Anesthesiology 21292 (1960)

4 Goodman, L S \& Gruman, A The Pharmacological Basis of Therapeutics, 2nd ed, pp 843-4 New York Macmillan (1955)

5 Shenkin, H A, Goluboff, B, \& Haft, H The Use of Manntol for the Reduction of Intracranial Pressure in Intracranial Surgery J Neurosurg 19897 (1962)

6 Smrth, E W \& Drance, S M Reduction of Human Intraocular Pressure with Intravenous Mannitol Arch Ophthalmol 68734 (1962)

7 Lilien, O M, Jones, S G, \& Mueller, C B The Mechanism of Mannitol Diuresis Surg, Gynec \& Obst 117221 (1963)

8 Barry, K G, Cohen, A, \& LeBlanc, P C, Jr Mannitolization I Prevention and Therapy of Oliguna Associated with Cross Clamping of Abdominal Aorta Surgery 50 $335(1961)$

9 Barry, $K$ B \& Berman, A R Mannitol Infusion III The Acute Effect of the Intravenous Infusion of Mannitol on Blood and Plasma Volumes New Engl J Med 264 1085 (1961)

10 Boba, A, Gainor, J, \& Powers, S R, JR The Influence of Mannitol on Water and Electrolyte Excretion Following Trauma Surgery 52188 (1982)

11 Parky, W L, Schaefer, J A, \& Mueller, C B Expenmental Studies of Acute Renal Falure I The Protective Effect of Mannitol J Urol 891 (1963) 
12 Attak, S, Borges, F, Crowley, R A, Esmond, W G, Holningsworth, N, \& Blati, E Use of Mannitol in Postperfusion Oliguna-Anuna Circulation $26 \quad 682$ (1962)

13 Beall, A C, Jr, Holman, M R, Morris, G C, JR, \& DeBakey, M E MannitolInduced Osmotic Diuresis dunng Vascular Surgery Arch. Surg 8634 (1963)

14 Harthorne, J W, Marcus, $\mathbf{A} M$, \& KAYE, $M$ Management of Massive Imipramine Overdosage with Mannitol and Artificial Dialysis New Engl. J Med 26833 (1963)

15 Galambos, J T, Herndon, E G, JR, Achord, J L, \& CFristy, J H The Effect of Osmotic (Mannitol) Diuresis on Electrolyte and Water Eircretion in Ascitic, Cirrhotic Patients Clin Res 1169 (1963)

16 Grossman, A \& Bernstein, L M The Use of the Osmotic Diuretic Mannitol in the Management of Refractory Nephrotic Syndrome Am J'Dis Children 102616 (1961)

17 BarRy, K G \& Mallory, J P Oliguric Renal Failure Evaluation and Therapy by the Intravenous Infusion of Mannitol J A M A 179510 (1962)

18 Barry, K G \& Crosby, W H The Prevention and Treatment of Renal Fallure Following Transfusion Reactions Transfusion 334 (1963)

19 Nahas, G G, Fink, R B, Ploski, W S, \& Tenen, R E The Depressant Effect of Tris (Hydroxymethylaminomethane) and of Mannitol on Respiration Ann N Y Acad Scl $109783(1963)$

20 Javim, $M$ \& Settlage, $P$ Effect of Urea on Cérebralspinal Fluid Pressure in Human Subjects J A M A 160943 (1956)

21 Jorgensen, H E \& Schlegel, J U Studies in Metabolism of Trauma III Postoperative Sodium Retention Surg Gynec \& Obst 108339 (1959)

22 Rosomoff, H L Effect of Hypothermia and Hypertonic Urea on Distnbution of Intracranial Contents J Neurosurg 18753 (1961)

23 Goodman, L S \& Gilman, A The Pharmacological Blasis of Therapeutics, 2nd ed, pp 841-2 New York Macmillan (1955)

24 Lich, R, Jn Kidneys, Fluids, and Electrolytes J Kentucky M A 53219 (1955)

25 Modell, W Drugs of Choice 1962-3, p 759 St Lous C V Mosby (1962)

26 Huckabes, W E Relationships of Pyruvate and Lactate durng Anaerobic Metabolism III Effect of Breathing Low-Oxygen Gases J Clin Investigation 37264 (1958)

27 Clowes, G H A, Alighniewiez, A, DelGuereio, L R M, \& Gillespie, D The Relatonship of Postoperative Acidosis to Pulmonary and Cardiovascular Function J Thorac Cardiovasc Surg 391 (1960)

28 Ebert, P A, Greenfield, L J , Austen, W G, \& Morrow, A The Relationship of Blood $\mathrm{pH}$ dunng Profound Hypothermia to Subsequent Myocardial Function Surg Gynec \& Obst 114357 (1962)

29 Thrower, W B, Darby, T D, \& Aldinger, E E Acid-Base Derangements and Myocardial Contractility Effects as a Complication of Shock A M A Arch Surg 8256 (1961)

30 Leidngham, I McA \& Norman, J N Acid-Base Studies in Expenmental Circulatory Arrest Lancet in 967 (1962)

31 Nahas, G G Use of an Organic Carbon Dioxide Buffer in vivo Science 129782 (1959)

32 Miller, R A, Brundle, F, \& Grlbert, , R G B Studies with an Organic Buffer (THAM) dunng Apnoeic Oxygenation in Dogs Bnt J Anaesth 323248 (1960).

33 Aldinger, E E, Darby, T D, \& Thrower, W. B Effects of Tns (Hydroxymethyl) Aminomethane (THAM) on Acid-Base Derangements and Ventricular Contractile Force Elicited by Penods of Reduced Curculatory Volume Fed Proc 19102 (1960)

34 Balagot, R C, Tsuji, H, \& Sadove, M S Use of an Osmotic Diuretic-THaM-in Treatment of Barbiturate Poisoning J A M A 178: 1000 (1981)

35 Brinkman, G L, Remp, D G, Coates, E O, \& Priest, E M Treatment of Respiratory Acidosis with THAM Am J Med Sc1 239341 (1960)

36 Kaplan, S, Fox, R P , \& Clark, L C, Jr Amine Buffers in the Management of Acidosis Am J Dis Children 1034 (1962)

37 Brinkman, G L The Use of THAM to Prevent Hyperventilation and Acidosis while Breathing Carbon Dioxide Am J Med Sc1 239728 (1960)

38 BennetT, T E \& TARAIL, $R$ The Hypoglycemic Activity of 2-Amino-2 hydroxy-methyl1,3-propanediol Ann N Y Acad Sc1 92 651 (1961).

39 Loewe, S Antagonısms and Antagonısts Pharmacol Rev 9237 (1957)

40 Leading Article Interaction between Drugs Lancet 11818 (1962)

41 Calesnick, B, Smrti, N $\mathbf{H}$, \& Beutner, $\mathrm{R}$ Combined Action of Cardiotoxic Study on Acute Toxicity of Combined Quinidine, Mependine, Pentobarbital, $P_{1}$ and Procaine Amide J Pharmacol \& Exper Therap 102138 (1951)

42 Snmeone, F A Surgery and Pharmacology Clin Pharmacol \& Therap 4149 (1963) 